Letter to the Editor

\title{
Vegetation and climate changes during the late Pliocene and early Pleistocene in SW Turkey - Response to comments by Elitez et al., Quaternary Research, 84, pp. 448-456
}

\author{
Keywords: \\ Pollen analysis \\ Paleovegetation \\ Paleoclimate \\ Pliocene \\ Pleistocene \\ SW Anatolia
}

They present the geological map as their own work, but it was extracted from the Geological Map Series of the Geological Survey of Turkey (MTA) compiled by Akdeniz (2011). They also did some computer mapping on a Google Earth image without citation. Elitez et al. failed to present any field evidences and instead showed logging and lithological observations on an old photo. They claim their unpublished evidence is stronger than international published data, and to justify their comments they cite personal communications with us that we are not aware of, and they cite non-scientific sources such as Research Gate. Such sites are unreliable personal domains, like Facebook, and the holder can change them arbitrarily.

Comments such as these do not contain any data refuting our arguments on Plio-Quaternary vegetation history of the Çameli Basin in SW Anatolia and do not stimulate discussion within the scientific community. Regardless, we direct them to read carefully preexisted studies on the Late Miocene-early Pleistocene extensional graben-type basins in SW Anatolia, including the Çameli Basin (Şenel, 1997a,b,c; Alçiçek et al., 2005, 2006, 2012, 2013a,b, 2015; Alçiçek, 2007, 2009, 2010, 2015; Alçiçek and Ten Veen, 2008; Ten Veen et al., 2009; Over et al., 2010, 2013a,b; Akdeniz, 2011; Helvacı et al., 2013; Alçiçek and Jiménez-Moreno, 2013; Alçiçek and Alçiçek, 2014; Jiménez-Moreno et al., 2015, 2016; van den Hoek Ostende et al., 2015a,b; Ozsayın, 2016).

Here we summary the stratigraphy of the Çameli Basin and its sedimentary infill to better inform the reader:

The Çameli Basin, ca. $40 \mathrm{~km}$ wide and $60 \mathrm{~km}$ long, is delimited by NE-trending basin-bounding normal faults (see Fig. 1 in JiménezMoreno et al., 2016). The basin resides on the Lycian nappes and consists of a series of NE-trending interconnected tilt-block compartments resulting from the NW-SE directed regional crustal extension. The basin formation in SW Anatolia was followed by final southeastward emplacement of the Lycian Nappes, which was sealed by Langhian shallow marine reef carbonates, and its nappe front was eventually covered by Serravalian shallow marine clastics to the southeast (Hayward and Robertson, 1982; Hayward, 1984; Collins and Robertson, 1997; Alçiçek and Ten Veen, 2008). Final movement of the nappes was followed by regional uplift, which caused NE-SW trending extension and resulted in grabentype depressions parallel to the nappe front. The age of basin-fill succession has been well determined as late Miocene (biozones MN9-12; Vallesian-Turolian chronozones) to early Pleistocene (biozone MN17; latest Villanyian chronozone) based on terrestrial macro- and micro-mammal associations (Alçiçek, 2001; Saraç, 2003; Alçiçek et al., 2005; Van den Hoek-Ostende et al., 2015a,b).

The basin-fill succession of the Çameli Basin has been identified as Çameli Formation and grouped into three lithostratigraphic 
subunits referred to as the Derindere, Kumafșarı and Değne members, consisting of alluvial, fluvial and lacustrine deposits, respectively. In the central part of the basin these members overlie each other in a 500-m-thick sequence, but they are laterally equivalent along the basin margins. The Derindere Member is composed of coarse-grained alluvial deposits and occurs typically in the lowerand also uppermost parts of the basin fill along the basin margins. It is about $60 \mathrm{~m}$ thick with dark-red colored matrix-supported conglomerates and mudstones, and passes laterally and vertically into the fluvial deposits. The Kumafşarı Member is widespread in the northern part of the basin and in the middle stratigraphic level of the basin fill, and it consists of up to $146 \mathrm{~m}$ of stacked fluvial deposits characterized by a light yellow color. This member passes laterally and vertically into lacustrine deposits. The Değne Member is composed of lacustrine deposits that vary from 75 to $300 \mathrm{~m}$ in thickness. The unit is common in southern parts of the basin and mainly constitutes the upper part of the basin succession, passing laterally and vertically into the fluvial deposits.

\section{References}

Alçiçek, M.C., 2001. Sedimentological investigation of the Cameli Basin (Late Miocene-Late Pliocene, Denizli, SW Anatolia). Unpubl. Ph. D. Thesis. Ankara University, p. 101.

Akdeniz, N., 2011. Geological Maps of Turkey in 1:100.000 Scale: Denizli N22 Sheet. Mineral Research and Exploration Directorate of Turkey, Ankara, 44 pp.

Alçiçek, M.C., Kazancı, N., Özkul, M., 2005. Multiple rifting pulses and sedimentation pattern in the Çameli Basin, southwestern Anatolia, Turkey. Sedimentary Geology $173,409-431$.

Alçiçek, M.C., Ten Veen, J.H., Özkul, M., 2006. Neotectonic development of the Çameli Basin, southwestern Anatolia, Turkey. In: Robertson, A.H.F., Mountrakis, D. (Eds.), Tectonic Development of the Eastern Mediterranean Region. Geological Society of London, Special Publication, vol. 260, pp. 591-611.

Alçiçek, M.C., 2007. Tectonic development of an orogen-top rift recorded by its terrestrial sedimentation pattern: the Neogene Essen Basin of southwestern Anatolia, Turkey. Sedimentary Geology 200, 117-140.

Alçiçek, M.C., Ten Veen, J.H., 2008. The late Early Miocene Acipayam piggy-back basin: refining the last stages of Lycian nappe emplacement in SW Turkey. Sedimentary Geology 208, 101-113.

Alçiçek, H., 2009. Late Miocene nonmarine sedimentation and formation of magnesites in the Acıgöl Basin, southwestern Anatolia, Turkey. Sedimentary Geology 219, 115-135.

Alçicek, H., 2010. Stratigraphic correlation of the Neogene basins in southwestern Anatolia: regional palaeogeographical, palaeoclimatic and tectonic implications. Palaeogeography, Palaeoclimatology, Palaeoecology 291, 297-318.

Alçiçek, M.C., Mayda, S., Alçiçek, H., 2012. Faunal and palaeoenvironmental changes in the Cal Basin, SW Anatolia: implications for regional stratigraphic correlation of late Cenozoic basins. Comptes Rendus Geoscience 344, 89-98.

Alçiçek, H., Jiménez-Moreno, G., 2013. Late Miocene to Pliocene fluvio-lacustrine system in Karacasu Basin (SW Anatolia, Turkey): depositional, palaeogeographic and palaeoclimatic implications. Sedimentary Geology 291, 62-83.

Alçiçek, M.C., Mayda, S., Titov, V.V., 2013a. Lower Pleistocene stratigraphy of the Burdur Basin of SW Anatolia. Comptes Rendus Palevol 12, 1-11.

Alçiçek, M.C., Brogi, A., Capezzuoli, E., Liotta, D., Meccheri, M., 2013b. Superimposed basin formation during Neogene-Quaternary extension in SW-Anatolia (Turkey): insights from the kinematics of the Dinar fault zone. Tectonophysics 608, 713-727.

Alçiçek, H., Alçiçek, M.C., 2014. Palustrine carbonates and pedogenic calcretes in the Çal basin of SW Anatolia: implication on the Plio-Pleistocene regional climatic pattern in the eastern Mediterranean. Catena 112, 48-55.

Alçiçek, H., Wesselingh, F., Alçiçek, M.C., 2015. Palaeoenvironmental evolution of the late Pliocene-early Pleistocene fluvio-deltaic sequence of the Denizli Basin (SW Turkey). Palaeogeograpy, Palaeoclimatology, Palaeoecology 437, 98-116.

Alçicek, M.C. 2015. Comment on The Fethiye-Burdur Fault Zone: a component of upper plate extension of the subduction transform edge propagator fault linking Hellenic and Cyprus Arcs, Eastern Mediterranean. Tectonophysics 635 80-99 by J. Hall, A.E. Aksu, İ. Elitez, C. Yaltırak, G. Çiftçi Tectonophysics 664, $1-4$.

Collins, A.S., Robertson, A.H.F., 1997. Lycian mélange, southwestern Turkey: an emplaced Late Cretaceous accretionary complex. Geology 25, 255-258.
Hayward, A.B., Robertson, A.H.F., 1982. Direction of ophiolite emplacement inferred from Cretaceous and Tertiary sediments of an adjacent autochthon, the Bey Dağlari, SW Turkey. Geological Society of American Bulletin 93, 68-75.

Hayward, A.B., 1984. Sedimentation and basin formation related to ophiolite emplacement, Miocene, SW Turkey. Sedimentary Geology 40, 105-129.

Helvacı, C., Alçiçek, M.C., Gündoğan, İ., Gemici, Ü., 2013. Tectonosedimentary development and palaeoenvironmental changes in the Acıgöl shallow-perennial playa-lake basin, SW Anatolia, Turkey. Turkish Journal of Earth Sciences 22, $173-190$.

Jiménez-Moreno, G., Alçiçek, H., Alçiçek, M.C., van den Hoek Ostende, L.W., Wesselingh, F.P., 2015. Vegetation and climatic cycles during the late Pliocene and early Pleistocene in SW Anatolia, Turkey. Quaternary Research 84, $448-456$.

Jiménez-Moreno, G., Alçiçek, H., Alçiçek, M.C., van den Hoek Ostende, L.W., Wesselingh, F.P., 2016. Corrigendum to "Vegetation and climatic cycles during the late Pliocene and early Pleistocene in SW Anatolia". Quaternary Research 85, 185-186.

Over, S., Yılmaz, H., Pınar, A., Özden, S., Ünlügenç, U.C., Kamacı, Z., 2013a. Plio-Quaternary stress state in the Burdur Basin, SW Turkey. Tectonophysics 588, 56-68.

Over, S. Özden, S., Yılmaz, H., Pınar, A., Ünlügenc, U.C., Kamacı, Z., 2013b. Plio-Quaternary stres regime in the Eşen Çay Basin, SW Turkey. In: Robertson, A.H.F., Parlak, O., Unlugenc, U.C. (Eds.), Geological Development of Anatolia and the Easternmost Mediterranean Region. Geological Society, London, pp. 547-560. Special Publications 372.

Over, S., Pınar, A., Özden, S., Yılmaz, H., Ünlügenç, U.C., Kamacı, Z., 2010. Late Cenozoic stress field in the Cameli Basin, SW Turkey. Tectonophysics 492, 60-72.

Ozsayın, E., 2016. Relative tectonic activity assesment of the Çameli Basin, Western Anatolia, using geomorphic indices. Geodinamica Acta. http://dx.doi.org/ 10.1080/09853111.2015.1128180.

Sarac, G., 2003. Türkiye Omurgalı Fosil Yatakları (Vertebrate Fossil Localities of Turkey). Scientific Report No. 10609. General Directorate of the Mineral Research and Exploration of Turkey (MTA), Ankara, p. 208.

Şenel, M., 1997a. Geological Maps of Turkey in 1:100000 Scale: Fethiye L8 Sheet. Mineral Research and Exploration Directorate of Turkey (MTA), Ankara, Turkey, $22 \mathrm{pp}$.

Şenel, M., 1997b. Geological Maps of Turkey in 1:100000 Scale: Fethiye M8 Sheet. Mineral Research and Exploration Directorate of Turkey (MTA), Ankara, Turkey, 15 pp.

Şenel, M., 1997c. Geological Maps of Turkey in 1:100000 Scale: Denizli K9 Sheet. Mineral Research and Exploration Directorate of Turkey (MTA), Ankara, Turkey, 17 pp.

Ten Veen, J.H., Boulton, S.J., Alçiçek, M.C., 2009. From palaeotectonics to neotectonics in the Neotethys realm: the importance of kinematic decoupling and inherited structural grain in SW Anatolia (Turkey). Tectonophysics 473, $261-281$.

van den Hoek Ostende, L.W., Diepeveen, F., Tesakov, A., Saraç, G., Mayhew, D., Alçiçek, M.C., 2015a. On the brink: micromammals from the latest Villanyian from Bıçakçı (Anatolia). Geological Journal 50, 230-245.

van den Hoek Ostende, L.W., Gardner, J.D., van Bennekom, L., Alçiçek, M.C., Murray, A.M., Wesselingh, F.P., Alçiçek, H., Tesakov, A.S., 2015b. Ericek, a new Pliocene vertebrate locality from the Çameli Basin (SW Anatolia, Turkey). Palaeobiodiversity and Palaeoenvironments 95, 305-320.

Gonzalo Jiménez-Moreno*

Departamento de Estratigrafía y Paleontología, Universidad de Granada, Fuente Nueva s/n, 18002, Granada, Spain

Hülya Alçiçek, Mehmet Cihat Alçiçek

Pamukkale University, Dept. of Geology, 20070, Denizli, Turkey E-mail addresses: halcicek@pau.edu.tr (H. Alçiçek), alcicek@pau.edu.tr (M.C. Alçiçek).

Lars van den Hoek Ostende, Frank P. Wesselingh Naturalis Biodiversity Center, P.O. Box 9517, 2300 RA, Leiden, The Netherlands

E-mail addresses: lars.vandenhoekostende@naturalis.nl (L. van den Hoek Ostende), frank.wesselingh@naturalis.nl (F.P. Wesselingh).

* Corresponding author. E-mail address: gonzaloj@ugr.es (G. Jiménez-Moreno).

15 March 2016 